Original Contribution

\title{
EFFECT OF DIETARY HERBAL ESSENTIAL OILS ON THE PERFORMANCE AND MEAT QUALITY OF FEMALE TURKEYS BROILERS
}

\author{
M. Oblakova ${ }^{1 *}$, P. Hristakieva ${ }^{1}$, N. Mincheva ${ }^{1}$, I. Ivanova ${ }^{1}$, M. Lalev ${ }^{1}$, N. Ivanov ${ }^{1}$, \\ I. Penchev ${ }^{2}$ \\ ${ }^{1}$ Department of Breeding and Technologies in Poultry and Rabbit, Agricultural Academy, Agricultural \\ Institute - Stara Zagora, Stara Zagora, Bulgaria \\ ${ }^{2}$ Department of Morphology, Physiology and Nutrition, Faculty of Agriculture, Trakia University, \\ Stara Zagora, Bulgaria
}

\begin{abstract}
During the last years, the addition of essential oils to livestock rations became increasingly popular. Numerous studies have proved the antibacterial properties of herbal essential oils (EO) along with antioxidant, anticarcinogenic and digestive properties. They are also used as growth promoters of livestock. With this regard, the purpose of the present study was to investigate the effect from addition of $0.01 \%$ essential oils (EO) from Matricaria chamomilla; Rosmarinus officinalis; Lavandula angustifolia; Origanum vulgare; Thymus vulgaris; Hypericum perforatum to the feed of turkey broilers on live body weight, feed consumption, slaughter traits, fatty acid content and meat quality. Female turkey broilers, were divided into 7 groups of 15 birds in each after being weighed and labelled (each group comprised 3 subgroups of 5 birds). Groups were one control (C) and six experimental (T1, T2, T3, T4, T5, T6). The control (C) group of turkeys received feed according to the requirements of their age without herbal essential oils. The experimental groups received the same diet supplemented as followed: group T1- $0.01 \%$ EO from Matricaria chamomilla; T2- 0.01\% EO from Rosmarinus officinalis; T3- 0.01\% EO from Lavandula angustifolia; T4-0.01\% EO from Origanum vulgare; T5$0.01 \%$ EO from Thymus vulgaris; T6- 0.01\% EO from Hypericum perforatum). The addition of $0.01 \%$ EO of abovementioned herbs influences breast and thigh meat $\mathrm{pH}$ measured at $24^{\text {th }}$ post mortem hour $\left(\mathrm{pH}_{24}\right)(\mathrm{P}<0.05)$. The highest value $\mathrm{L}^{*}$ in breast meat was demonstrated in birds supplemented with EO from Lavandula angustifolia (T3) and lowest $\mathrm{L}^{*}$ in group $\mathrm{T} 5$ at $(\mathrm{P}<0.05)$. The highest value $\mathrm{L}^{*}$ in thigh meat was measured in birds from group T2 (EO from Rosmarinus officinalis) and the lowest- in group T5 (EO from Thymus vulgaris). The redness $\left(\mathrm{a}^{*}\right)$ and yellowness $\left(\mathrm{b}^{*}\right)$ of breast meat did not differ significantly among the groups $(\mathrm{P}>0.05)$, yet $\mathrm{a}^{*}$ and $\mathrm{b}^{*}$ values showed considerable differences in thigh meat $(\mathrm{P}<0.05)$. The dietary EO also had an effect on thigh meat $\mathrm{L}^{*}, \mathrm{a}^{*}$ and $\mathrm{b}^{*}$ - parameters of meat colour. Cooking loss $\%$ of breast meat was the highest in the control group- $35.12 \%$ and the lowest in group T5 (Thymus vulgaris EO) - 23.69\% and group T6 (Hypericum perforatum EO) - 24.78\% $(\mathrm{P}<0.001)$. The addition of herbal EO to the ration of turkey broilers did not influence the content of saturated and unsaturated fatty acids (linoleic acid, $\alpha$-linolenic acid, arachidonic acid, eicosapentaenoic acid and docosahexaenoic acid) of breast and thigh meat of birds from experimental groups.
\end{abstract}

Key words: Turkeys, performance, essential oil from herbs, quality meat, fatty acids

\section{INTRODUCTION}

Herbs are a new class of growth promoters which recently has gained popularity in the fodder industry. The variety of herbs, spices

\footnotetext{
*Correspondence to: M. Oblakova, Department of Breeding and Technologies in poultry and rabbit, Agricultural Academy, Agricultural Institute - Stara Zagora, Radnevsko road 1, 6000 Stara Zagora, Bulgaria,moblakova@abv.bg
}

and their products and essential oils is substantial. Numerous studies have proved that Herbal essential oils (EO) have antibacterial, antioxidant, anti-inflammatory, anticarcinogenic, health promoting and digestive properties (1-5). They are also used as growth promoters in livestock nutrition (6-9). Essential oils (EO) improve the digestibility through optimisation of intestinal microbiota, stimulation of secretion of digestive enzymes 
OBLAKOVA M., et al.

and improvement of growth performance in domestic poultry $(7,10)$. Malayoglu et al. (11) and Roofchaee et al. (12) reported that dietary supplementation with oregano exhibited a growth-promoting effect. Marcinčák et al. (13) found out that broiler chickens supplemented with oregano essential oil showed higher body weight $(2563 \pm 140 \mathrm{~g})$ that non supplemented birds $(2462 \pm 195 \mathrm{~g})$. Agus et al. (14) demonstrated that the addition of a mixture of nine plants EO in the drinking water $(1 \mathrm{ml} / 1 \mathrm{l})$ influenced the slaughter yield, cooking loss, tenderness and water holding capacity of broiler meat. No differences in live weight and feed conversion were noticed. Botsologlu et al. (15) and Hernandez et al. (16) also showed that the addition of plant extracts to broiler chickens' diet did not influence feed conversion ratio. Kirkpınar et al. (17) supported these findings with lack of significant differences in live weight and feed conversion ratio of experimental birds supplemented with oregano and garlic oil and control birds. Lee et al. (18) and Ocak et al. (19) added a mixture of herbal EO to the ration of broiler chickens and established a substantial improvement of feed conversion ratio. When the broilers were fed a diet supplemented with EO from peppermint and thyme at 24 and $48 \mathrm{mg} / \mathrm{kg}$ feed, feed conversion was better and mortality rate lower than those in controls. Méndez et al. (20) reported that the addition of $0.4 \mathrm{mg} / \mathrm{kg}$ Mexican oregano EO resulted in a positive effect on body weight and feed intake of chickens. Mexican oregano EO could be used as a dietary supplement in broilers' rations. In available literature, investigations on the influence of dietary herbal essential oils on productive performance and meat quality in turkeys are scarce.

The purpose of the present study was to investigate the effect from addition of $0.01 \%$ essential oils from herbs (Matricaria chamomilla; Rosmarinus officinalis; Lavandula angustifolia; Origanum vulgare; Thymus vulgaris; Hypericum perforatum) to the feed of turkey broilers on live body weight, feed consumption, slaughter traits, meat chemical and fatty acid content and meat quality.

\section{MATERIALS AND METHODS Experimental design}

The experiment was carried out in the experimental base of the Agricultural Institute, Stara Zagora from May to September 2019. A day- old female turkey broilers were divided in 7 groups after being weighed and labelled. Birds were reared in separate boxes, on the floor, on wooden shavings from day 1 to day 126 of age. The first week of life, circles for maintaining the temperature and corrugated card box to limit pecking of shavings were used. Birds had ad libitum access to feed and water and continuous lighting was provided. Groups were one control (C) and six experimental (T1, T2, T3, T4, T5, T6). The control (C) group of turkeys received feed according to the requirements of their age without herbal essential oils. The experimental groups received the same diet supplemented as followed: group T1- $0.01 \%$ EO from Matricaria chamomilla; T2- $0.01 \%$ EO from Rosmarinus officinalis; T3- $0.01 \%$ EO from Lavandula angustifolia; T4- $0.01 \%$ EO from Origanum vulgare; T5- $0.01 \%$ EO from Thymus vulgaris; T6- $0.01 \%$ EO from Hypericum perforatum. At 56 days of age from these groups of broiler turkeys were selected 15 turkeys from each group with average live weight (each group was divided into 3 subgroups of 5 turkeys) in boxes.

The basal diet was formulated for starter (Starter 1 from 1 to 21 day- old turkey- Crude protein-28\% and Metabolic energy- 2800 $\mathrm{kcal} / \mathrm{kg}$; Starter 2- from 22 to 42 day- old turkey- Crude protein- 26\% and Metabolic energy- $2900 \mathrm{kcal} / \mathrm{kg}$; Starter 3- from 43 to 55 day- old turkey- Crude protein- $24 \%$ and Metabolic energy- $3000 \mathrm{kcal} / \mathrm{kg}$ ), grower (Grower 1 from 56 to 84 day old turkey Crude protein- 22\% and Metabolic energy$3100 \mathrm{kcal} / \mathrm{kg}$; Grower 2- from 85 to 100 day old turkey - Crude protein-19\% and Metabolic energy- $3250 \mathrm{kcal} / \mathrm{kg}$ ) and finisher (Finisher from 101 to 126 day old turkey- Crude protein$17 \%$ and Metabolic energy- $3350 \mathrm{kcal} / \mathrm{kg}$ ) growth periods. All diets were in mashed form. Body weight (BW) and feed intake (FI) were recorded by treatment group, and FCR (feed conversion ratio) per group were then calculated for the total experimental period.

\section{Slaughter procedures and carcass evaluation}

At the end of the experiment, 35 turkeys (5 birds per group) representing the average body weight of each group were selected and after 12-h fasting time were slaughtered at the own experimental slaughterhouse. After evisceration the hot carcasses were weighed to evaluate dressing yield expressed as a percentage of pre-slaughter body weight. 
Thereafter, the carcasses were cut into parts. The carcass parameters measured were - whole breast, whole legs, back, wings, neck, heart, gizzard, liver. Abdominal fat was removed and weighed individually. The breast $(m$. Pectoralis superficialis and $m$. Pectoralis profundus) and thigh (m. Femorotibialis) muscles were deboned for the determination the fatty acid profile, stored in hermetically sealed bags and kept at $-20^{\circ} \mathrm{C}$ until analysis.

\section{Analysis of Quality of Meat}

Meat proximate analysis comprised moisture, protein and fat in breast muscles (m. Pectoralis superficialis and $m$. Pectoralis profundus) and thigh muscles (m. Femorotibialis). Meat moisture content was determined by drying in an oven at $105^{\circ} \mathrm{C}$. Moisture content was analysed according to (21). Meat protein content was determined as per (22). To this end, a UDK 149 Automatic Kjeldahl Distillation Unit (VELP Scientifica, Italy) was used. Fat content was determined by Soxhlet extraction as per (23). The $\mathrm{pH}\left(\mathrm{pH}_{24}\right)$ was determined by $\mathrm{pH}$-meter „Testo 205“into the breast and thigh muscles 24 hours after slaughter. The muscle colour was evaluated in the CIE $\mathrm{L}^{*}, \mathrm{a}^{*}, \mathrm{~b}^{*}$ colour space, where $\mathrm{L}^{*}$ is lightness, $\mathrm{a}^{*}$ - redness and $\mathrm{b}^{*}$ - yellowness of meat. Colour coordinates were determined with a colorimeter Minolta CR-400 (Konica Minolta, Osaka, Japan), with illuminate D65 and observation angle $2^{\circ}$.
OBLAKOVA M., et al. Water holding capacity of meat (WHC \%) was determined by pressing it using the classical method of Grau and Hamm described by Zahariev and Pinkas, (24) with modifications by Petrov, (25).

Cooking loss (\%) was determined by cooking the meat sample at $150^{\circ} \mathrm{C}$ for 20 minutes in a forced air convection oven. Cooking loss was calculated as the difference in weight of samples before and after cooking. The fatty acid content of breast and thigh samples was determined of gas chromatography after extraction and transformation of fatty acids in methyl esters. Fatty acids were expressed as a percentage of the sum of identified fatty acids.

\section{Statistical Analysis}

Statistical analyses were conducted with STATISTICA program, ver. 10 (StatSoft, Inc., 2011). One-way analysis of variance (ANOVA) tests were performed to compare means of all data. Dependent on the variance homogeneity (evaluated by Levene's test), identification of significant differences $(P<0.05)$ was carried out making use of the LSD post-hoc test, while for nonparametric analysis was used the Kruskal-Wallis test.

\section{RESULTS AND DISCUSSION}

Table 1 presents body weights at 126 days of age, average daily gain, average feed consumption and feed conversion ratio from 56 to 126 day of age of turkey broilers.

Table 1. Effects of dietary treatments on broilers' performance

\begin{tabular}{|lcccc|}
\hline Treatment & \multicolumn{4}{c|}{ Parameters } \\
& BW & ADG & AFC & FCR \\
\hline C & 9873.33 & 0.097 & 0.312 & 3.333 \\
T1 & 9673.33 & 0.099 & 0.320 & 3.310 \\
T2 & 9793.33 & 0.097 & 0.326 & 3.366 \\
T3 & 9850.00 & 0.101 & 0.323 & 3.244 \\
T4 & 9338.46 & 0.095 & 0.320 & 3.267 \\
T5 & 9966.67 & 0.109 & 0.328 & 3.027 \\
T6 & 10081.82 & 0.116 & 0.327 & 2.811 \\
& & & & \\
\hline SEM & 62.51 & 0.003 & 0.002 & 0.076 \\
P-value & 0.064 & 0.256 & 0.995 & 0.558 \\
\hline
\end{tabular}

Note: The means within the same column with at least one common letter, do not have significant difference $(\mathrm{P}>0.05)$. SEM: standard error of the means; BW(кg): body weight at 126 day of age; ADG- Average Daily Gain $(\mathrm{kg})$, AFC- Average Feed Consumption (kg/day ) and FCR - feed conversion ratio (kg/ kg) for 56- 126 day of age

The addition of $0.01 \%$ herbal EO to the feed of turkey broilers had no significant effect on final body weight at 126 days of age. The highest weight was that of birds from group
T6, supplemented with EO from $H$. perforatum- $10081.82 \mathrm{~kg}$ and the lowest- in group T4 (supplemented with EO from Thymus vulgaris- $9338.46 \mathrm{~kg}$ ), but the differences were 
OBLAKOVA M., et al.

statistically unproven $(\mathrm{P}>0.05)$ (Table 1). The average daily gain and the feed conversion ratio from 56 to 126 days of age were not influenced by feed supplemented with herbal EO ( $P>0.05)$. This finding disagrees with data of Al- Kassie, (26) reporting that chickens fed diets supplemented with $200 \mathrm{ppm}$ thyme EO showed considerably higher weight gain. Fotea et al. (27) also reported higher final body weight by $13 \%$ in chickens supplemented with thyme essential oil compared to control birds. Yet, the research results of Sevim et al. (28) found no effect from feed supplementation with rosemary EO on final body weight and feed intake of chukar partridges $(\mathrm{P}>0.05)$. Other studies also confirmed the lack of significant influence of dietary plant extracts on average daily gain and feed conversion ratio $(7,15-16)$.

The effect of herbal EO added to the feed of turkey broilers on slaughter traits are shown in Table 2. The addition of $0.01 \%$ EO to the feed had no effect on slaughter yield and breast yield in the present study $(\mathrm{P}>0.05)$. A number of studies have reported the effects of dietary phytogenic compounds- extracts of rosemary and salvia (29), rosemary (30) and rosemary and oregano EO (31-32) on slaughter traits of poultry. They however did not demonstrate significant beneficial effect of phytoadditives on carcass yield and carcass cut-up parts yields (33-34). These findings are contrary to those of Agus et al. (14), who confirmed increased slaughter yield by $10.87 \%$ in broiler chickens supplemented with a mixture of EO in drinking water in comparison to control broilers. Other studies in line with these findings are those of Roofchaee et al. (12) and Alçiçek et al. (35). Our study, however, demonstrated considerably differences in thigh and breast percentage from body weight $(\mathrm{P}<0.05)$ in studied groups of turkey poults. The highest thigh percentage was found in group T6 (EO from H.perforatum), and the lowest - in control group $(28.72 \%)$. Back percentage was the highest in control group- $21.97 \%$, followed by T1- $20.36 \%$ while the lowest back percentage was that of group T6- $18.70 \%(\mathrm{P}<0.05)$.

Table 2. Carcass characteristics of turkeys at 126 days of age, $\%$

\begin{tabular}{|llllllllll|}
\hline Parameters & \multicolumn{7}{c}{ Treatment } \\
& $\mathrm{C}$ & $\mathrm{T} 1$ & $\mathrm{~T} 2$ & $\mathrm{~T} 3$ & $\mathrm{~T} 4$ & $\mathrm{~T} 5$ & $\mathrm{~T} 6$ & SEM & P-value \\
\hline CY, \% & 77.83 & 76.53 & 76.30 & 75.60 & 75.44 & 76.77 & 75.78 & 0.24 & 0.087 \\
Breast*, \% & 37.02 & 36.56 & 38.31 & 38.48 & 37.89 & 37.87 & 36.79 & 0.32 & 0.638 \\
Thigh, \% & $28.72^{\mathrm{c}}$ & $31.18^{\mathrm{ab}}$ & $31.04^{\mathrm{b}}$ & $30.64^{\mathrm{bc}}$ & $30.74^{\mathrm{b}}$ & $31.00^{\mathrm{b}}$ & $33.12^{\mathrm{a}}$ & 0.34 & 0.016 \\
Wings, \% & 11.34 & 11.90 & 11.11 & 11.36 & 11.60 & 11.22 & 11.38 & 0.11 & 0.523 \\
Back, \% & $21.97^{\mathrm{a}}$ & $20.36^{\mathrm{ab}}$ & $19.50^{\mathrm{b}}$ & $19.43^{\mathrm{b}}$ & $19.68^{\mathrm{b}}$ & $19.95^{\mathrm{b}}$ & $18.70^{\mathrm{b}}$ & 0.28 & 0.028 \\
Gizzard, \% & 1.34 & 1.19 & 1.11 & 1.15 & 1.33 & 1.15 & 1.23 & 0.12 & 0.088 \\
Liver, \% & 1.18 & 1.17 & 1.08 & 1.12 & 1.03 & 0.99 & 1.01 & 0.03 & 0.337 \\
Heart, \% & 0.36 & 0.35 & 0.40 & 0.35 & 0.39 & 0.36 & 0.35 & 0.01 & 0.791 \\
Abdom.fat, \% 1.17 & 1.51 & 1.47 & 1.40 & 1.57 & 1.67 & 1.67 & 0.08 & 0.412 \\
\hline
\end{tabular}

Note:a,b,c,d,e- different superscripts within a row indicate statistically significant differences at $\mathrm{P}<0.05$ in nonparametric Kruskal-Wallis test (\% wings, \% gizzards and \% abdominal fat); \% of viscera and abdominal fat was calculated with respect to body weight, and carcass cuts -vs grill weight; *breast with bone; CY - Carcass yield

Table 3 presents moisture, protein and fat contents $(\%)$ in breast and thigh meat of birds from control and experimental groups. There were no consistent differences $(\mathrm{P}>0.05)$ in breast meat moisture, protein and fat percentages among the groups. Thigh meat protein and fat contents were neither statistically significantly different. Moisture of thigh meat varied from $70.50 \%$ in turkey broilers whose feed was supplemented with thyme EO to $73.08 \%$ in the group that received oregano EO ( $\mathrm{P}>0.05)$. Karakok et al. (36) have performed a comparative study on the moisture, protein and fat contents of various meats and reported that moisture content of turkey meat was $73.12 \%$, that of proteins$24.38 \%$, and of fats- $1.19 \%$. Elimali et al. (37) observed no between-group and between-sex significant differences $(\mathrm{P}>0.05)$ of meat dry matter, crude protein in Japanese quails whose drinking water was supplemented with $1 \mathrm{ml}$ or $1.5 \mathrm{ml}$ plant extracts per 51 water. However, Herkel et al. (38) reported that the addition of a mixture of phytogenic essential oils from oregano, anise and citrus fruits as well as of prebiotics (fructooligosaccharides) at a dose of $1 \mathrm{~kg} / 100 \mathrm{~kg}$ compound feed resulted to increased dry matter and fat in the liver, and crude protein and ash content of muscles of turkeys. 
Table 3. Chemical analysis of breast and thigh meat

OBLAKOVA M., et al.

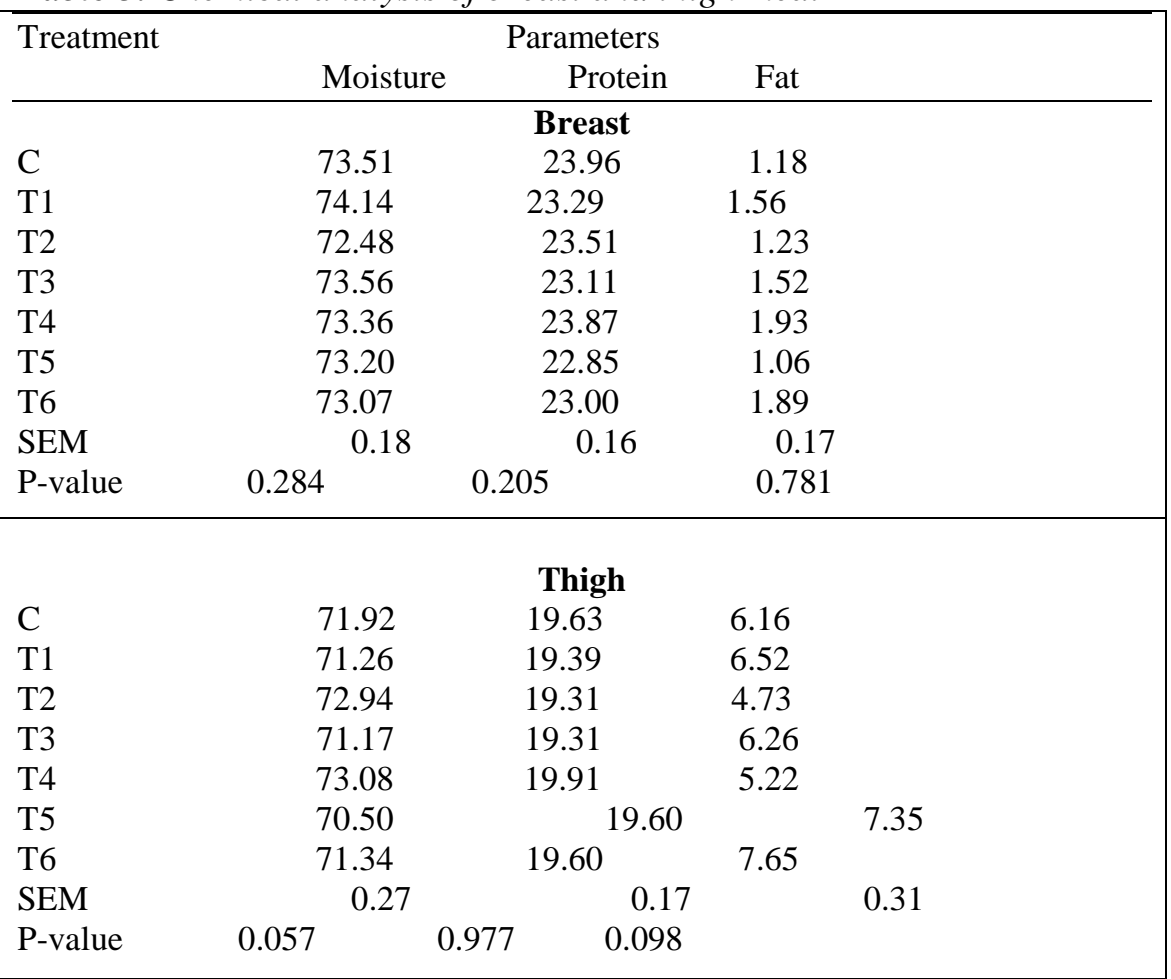

The values of $\mathrm{pH}_{24}$, meat colour coordinates $\left(\mathrm{L}^{*}, \mathrm{a}^{*}, \mathrm{~b}^{*}\right), \mathrm{WHC} \%$ and cooking loss percentages of breast and thigh turkey meat are presented in Table 4. The breast and thigh meat $\mathrm{pH}$ measured $24 \mathrm{~h}$ post mortem differed significantly between control and experimental groups $(\mathrm{P}<0.001)$. The highest breast meat
$\mathrm{pH}_{24}$ was found out in group $\mathrm{T} 1-5.73$ (Matricaria chamomilla EO) and group T35.71 (Lavandula angustifolia EO) whereas the lowest was that of group T4 (Origanum vulgare $\mathrm{EO}$ ) and $\mathrm{T} 6$ (Hypericum perforatum $\mathrm{EO})$.

Table 4. Meat quality

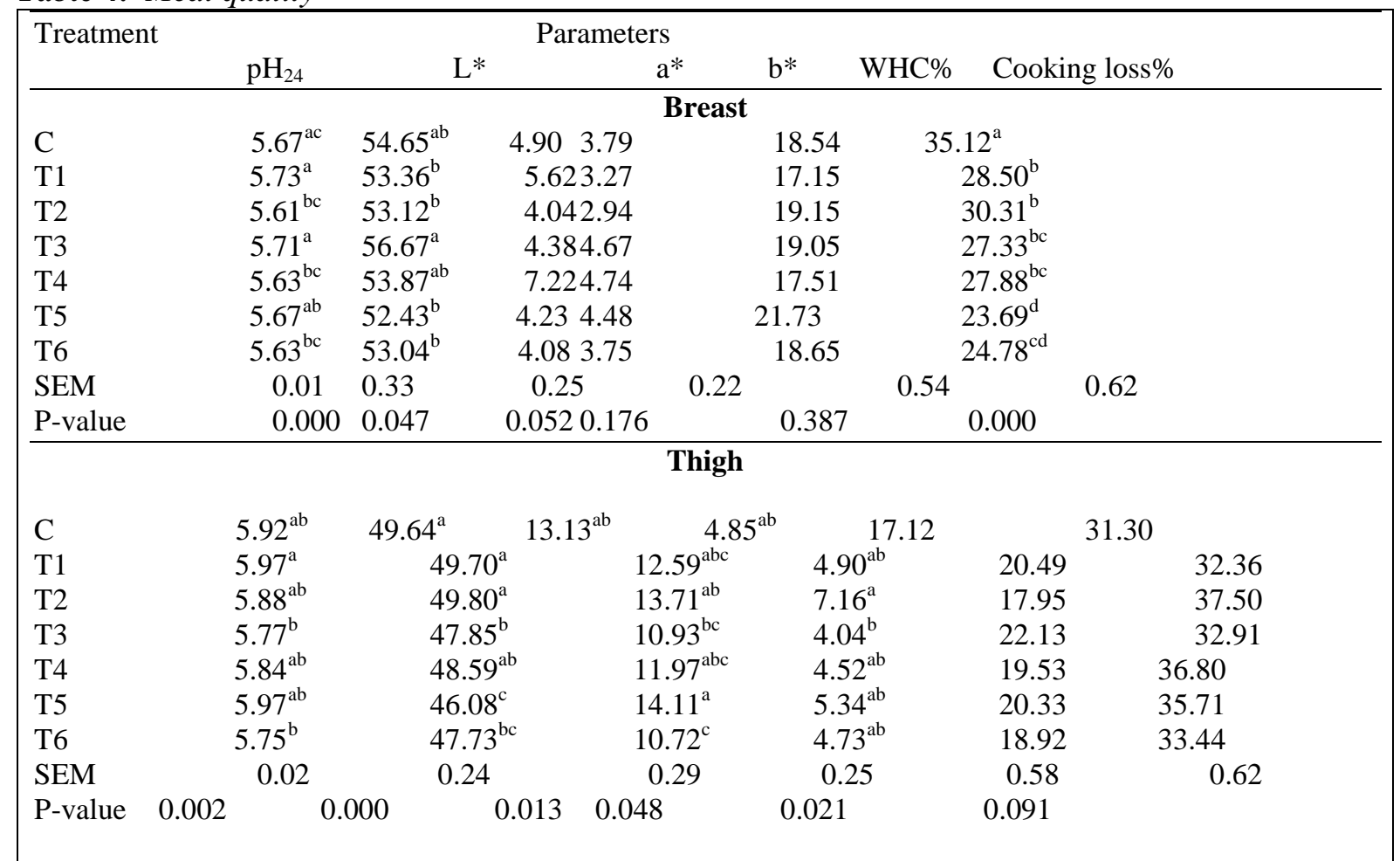

a-d - different superscripts within a column indicate statistically significant differences at $\mathrm{P}<0.0$; Non parametric Kruskal- Wallis test for $\mathrm{pH}_{24}, \mathrm{~L}^{*}, \mathrm{a}^{*}, \mathrm{~b}^{*}$ 
OBLAKOVA M., et al.

For thigh meat, the highest $\mathrm{pH} 24$ of 5.97 was observed again in T1 group (EO from Matricaria chamomilla) and the lowest- in group T6 (EO from Hypericum perforatum)5.75. Lightness $\left(\mathrm{L}^{*}\right)$ values of breast meat differed statistically significantly $(\mathrm{P}<0.05)$. Values in all groups were higher than 50, which is associated with PSE (39). The highest value $\mathrm{L}^{*}$ in breast meat were demonstrated in birds supplemented with EO from Lavandula angustifolia -56.67 and lowest $\mathrm{L}^{*}$ in group T5- 52.43 $(\mathrm{P}<0.05)$. The highest value $\mathrm{L}^{*}$ in thigh meat was measured in birds from group T2 (EO from Rosmarinus officinalis)- 49.80 and the lowest- in group T5 (EO from Thymus vulgaris)- 46.08. Küçükyilmaz et al. (40) observed increased lightness of meat in broilers supplemented with $24 \mathrm{mg} / \mathrm{kg}$ and 48 $\mathrm{mg} / \mathrm{kg}$ feed lavender EO (Lavandula stoaches): 58.49 and 58.38 respectively, compared to 56.29 in control group. The redness $\left(\mathrm{a}^{*}\right)$ and yellowness $\left(b^{*}\right)$ of breast meat did not differ significantly among the groups $(\mathrm{P}>0.05)$, yet $a^{*}$ and $b^{*}$ values showed considerable differences in thigh meat $(\mathrm{P}<0.05)$. Waterholding capacity $(\mathrm{WHC} \%)$ is one of the most important quality attributes of meat, in particular with regard to its processing suitability. Water-holding capacity (WHC) has been correlated with muscle $\mathrm{pH}$, indicating that lower cooking losses are associated with higher muscle $\mathrm{pH}$ and better protein functionality (39). In this study, there were no relevant differences with respect to $\mathrm{WHC} \%$ in the breast and thigh meat of studied groups of birds. Breast meat cooking loss\% was the highest in control turkey broilers- $35.12 \%$ and the lowest in groups supplemented with Thymus vulgare EO- $23.69 \%$ and Hypericum perforatum EO- $24.78 \%(\mathrm{P}<0.001)$. For this parameter, between-group differences in thigh meat were not considerable.

Table 5 presents the content of saturated fatty acids, linoleic acid, ó-linolenic acid, Arachidonic acid, eicosapentaenoic acid and docosahexaenoic acid in breast and thigh meat of studied groups of turkey broilers.

Table 5. Effects of dietary herbs supplement essential oil on fatty acid composition (\%) of thigh and breast meat in turkeys at 126 day of age

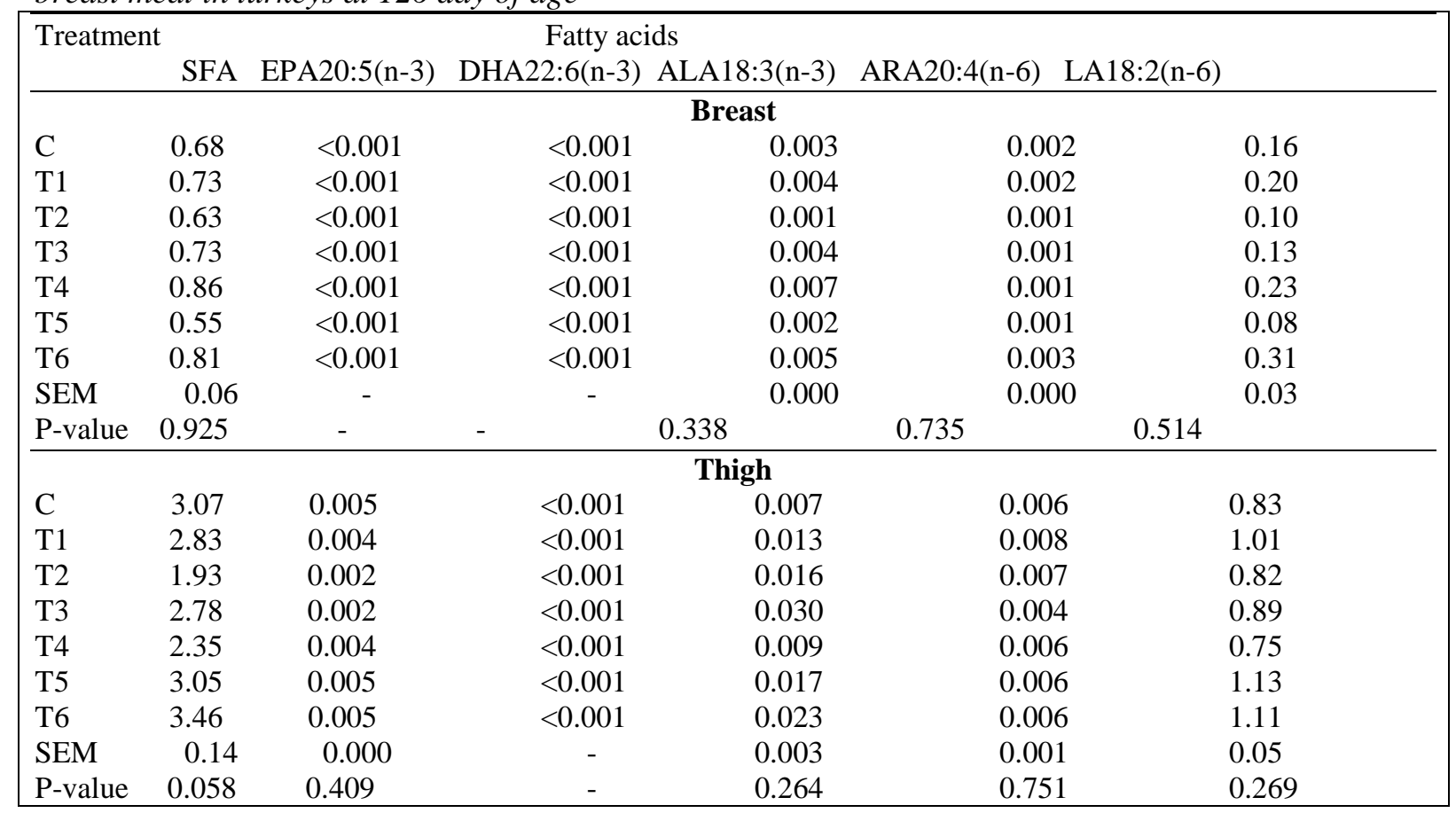

*-SFA- saturated fatty acids; EPA- Eicosapentaenoic acid; DHA- Docosahexaenoic acid; ALA -ó-linolenic acid; ARA - Arachidonic acid; LA- Linoleic acid

The increase in polyunsaturated fatty acids in meat influences not only lipid oxidation, but also meat colour, flavour and oxidative stability (31). The analysis of saturated fatty acid content of breast and thigh meat of turkeys did not differ considerably in the present study. The content of EPA20:5(n-3)- eicosapentaenoic acid in breast meat was $<0.001$ in all studied groups, in line with data reported by Ribarski and Oblakova (41) for lack of (n-3)- eicosapentaenoic acid in female wild turkeys and content of $1.73 \%$ in the breast meat of female turkey poults. The differences with regard to the other studied unsaturated 
OBLAKOVA M., et al.

fatty acids in breast and thigh meat of all groups were not significant. The addition of herbal EO to turkey feed had no effect on the content of unsaturated fatty acids, linoleic acid, ó-linolenic acid, arachidonic acid, eicosapentaenoic acid and docosahexaenoic acid in thigh meat of studied groups. In a study of Smet et al. (42) with broiler chickens and of Elmalı et al. (37) with quails, whose diets were supplemented with various plant extracts, no substantial effect on meat fatty acid content was demonstrated, which is in line with results from the present study. İpçak and Alçiçek, (43), have investigated the effect of main ingredients carvacrol in thyme essential oil (Origanum vulgare), cinnamaldehyde from cinnamon essential oil (Cinnamomum zeylanicum) and oleoresin from capsicum in Capsicum annuum added at $150 \mathrm{mg} / \mathrm{kg}$ feed on fatty acid content of breast and thigh meat of broiler chickens. They found out increased content of C20:5n-3 eicosapentaenoic acid and C20:1 eicosanoid acid of breast meat in birds supplemented with a mixture of the three additives in comparison to the other groups.

\section{CONCLUSION}

The addition of $0.01 \%$ EO from Matricaria chamomilla; Rosmarinus officinalis; Lavandula angustifolia; Origanum vulgare; Thymus vulgaris; or Hypericum perforatum to turkey broiler feed influenced significantly $(\mathrm{P}<0.05)$ thigh and breast meat $\mathrm{pH}$ measured on post mortem hour 24. The tested essential oils supplements resulted in statistically significant differences in breast and thigh meat lightness $\left(\mathrm{L}^{*}\right)(\mathrm{P}<0.05)$. The highest value $\mathrm{L}^{*}$ in breast meat were demonstrated in birds supplemented with EO from Lavandula angustifolia (T3) - 56.67 and lowest $\mathrm{L}^{*}$ in group T5- $52.43(\mathrm{P}<0.05)$. The highest value $\mathrm{L}^{*}$ in thigh meat was measured in birds from group T2 (EO from Rosmarinus officinalis)49.80 and the lowest- in group T5 (EO from Thymus vulgaris $)$ - 46.08. The redness $\left(\mathrm{a}^{*}\right)$ and yellowness $\left(b^{*}\right)$ of breast meat did not differ significantly among the groups $(\mathrm{P}>0.05)$, yet $\mathrm{a}^{*}$ and $\mathrm{b}^{*}$ values showed considerable differences in thigh meat $(\mathrm{P}<0.05)$. Cooking loss $\%$ of breast meat was the highest in control birds - $35.12 \%$ and the lowest - in group T5 (EO from Thymus vulgaris) - 23.69\% and group T6 (EO from Hypericum perforatum $)-24.78 \%(\mathrm{P}<0.001)$. The essential oil supplements did not alter significantly the content of saturated and unsaturated fatty acids, linoleic acid, $\alpha$ - linolenic acid, arachidonic acid, eicosapentaenoic acid and docosahexaenoic acid in breast and thigh meat of studied groups of turkeys.

\section{ACKNOWLEDGEMENTS}

The present study is a part of the project "Opportunities for obtaining functional foods from poultry"- $\quad$ №KП-06- $\Gamma \quad$ 26/3 from 04.12.2018 funded by the Bulgarian National Science Fund in the competition for Financial Support for a basic research project.

\section{REFERENCES}

1. Viuda- Martos, M., Ruiz- Navajas, Y., Fernandez- Lopez, J., Perez-Alvarez, J. A., Effect of adding citrus waste water, thyme and oregano essential oil on the chemical, physical and sensory characteristics of a bologna sausage. Innovative Food Science and Emerging Technologies, 10, 655-660, 2009.

2. Viuda- Martos, M., Ruiz- Navajas, Y., Fernandez- Lopez, J., Perez-Alvarez, J. A., Spices as functional foods. Critical Reviews in Food Science and Nutrition, 51(1), 13-28, 2011.

3. Gerzilov, V., Nikolov, A., Petrov, P. Bozakova, N., Penchev, G., Bochukov, A., Effect of dietary herbal mixture supplement on the growth performance, egg production and health status in chickens. Journal of central European Agriculture, 16,1 0-27, 2015.

4. Zhai, H., Liu, H., Wang, S., Wu, J., Kluenter, A.M., Potential of essential oils for poultry and pigs. Animal Nutrition, 4, 179-186, 2018.

5. Yang, X., Liu, Y., Yan, F., Yang, C., Yang, $\mathrm{X}$., Effects of encapsulated organic acids and essential oils on intestinal barrier, microbial count, and bacterial metabolites in broiler chickens. Poultry Science, 98, 2858-2865, 2019.

6. Cross, D.E., Acamovic, T., Deans, S.G., Cdevitt, R.M., The effects of dietary inclusion of herbs and their volatile oils on the performance of growing chickens. British Poultry Science, 43, 33-35, 2002.

7. Cross, D. E., McDevitt, R. M., Hillman, K., Acamovic, T., The effect of herbs and their associated essential oils on performance, dietary digestibility and gut microflora in chickens from 7 to 28 days of age. British Poultry Science, 48, 496-506, 2007.

8. Bampidis, V.A., Christodoulou, V., FlorouPaneri, P., Christaki, E., Chatzopoulou, P.S., Tsiligianni, T., Spais, A.B., Effect of 
dietary dried oregano leaves on growth performance, carcase characteristics and serum cholesterol of female early maturing turkeys. British Poultry Science, 46, 595601, 2005.

9. Zhang, Y., Gong, J., Yu, H., Guo, Q., Defelice, C., Hernandez, M., Yin, Y., Wang, Q., 2014. Alginate-whey protein dry powder optimized for target delivery of essential oils to the intestine of chickens. Poultry Science, 93, 2514-2525, 2014.

10.Lovkova, M.Y., Buzuk, G.N., Sokolova, S.M., Klimenteva, N.I., Chemical features of medicinal plants. Appl. Biochem. Microbiol. 37, 229-37, 2001.

11.Malayoglu, H.B., Baysal, S., Misirlio glu, Z, Polat, M, Yilmaz, H., Turan, N., Effects of oregano essential oil with or without feed enzymes on growth performance, digestive enzyme, nutrient digestibility, lipid metabolism and immune response of broilers fed on wheat-soybean meal diets. British Poultry Science, 51, 67-80, 2010.

12.Roofchaee, A., Irani, M., Mohammad, A.E. Mohammad, R.A., Effect of dietary oregano (Origanum vulgare L.) essential oil on growth performance, cecal microflora and serum antioxidant activity of broiler chickens. African Journal of Biotechnology, 10, 6177-6183, 2011.

13.Marcinčák, S., Cabadaj, R., Popelka, P., Šoltýsová, L., Antioxidative effect of oregano supplemented to broilers on oxidative stability of poultry meat. Slov Vet Res, 45 (2), 61-6, 2008.

14.Agus, A., Anas, M. A., Luthfiana, R., Hidayat, A.A., Effect of blend of natural essential oils addition in the drinking water on productivity, carcass yield and meat quality of broiler. Conference Series: Earth and Environmental Science, Volume 387, The 8th International Seminar on Tropical Animal Production 23-25 September 2019, Yogyakarta, Indonesia, 2019.

15.Botsoglou NA, Christaki E, Florou-Paneri P, Giannenas I, Papageorgiou G and Spais $A B$. The effect of a mixture of herbal essential oils or $\alpha$-tocopheryl acetate on performance parameters and oxidation of body lipid in broilers. South African Journal Of Animal Science, 34, 52-61, 2004.

16.Hernandez, F., Madrid, J., Garcia, V., Orengo, J., Megias, M. D., Influence of two plant extracts on broiler performance, digestibility, and digestive organ size. Poultry Science, 83, 169-74, 2004.
OBLAKOVA M., et al.

17.Kirkpinar, F., Ünlü, H.B., Özdemir, G., Effects of oregano and garlic essential oils on performance, carcase, organ and blood characteristics and intestinal microflora of broilers. Livestock Science 137, 219-225, 2011.

18.Lee, K., Everest, W.J., Kappert, H.J., Yeom, K.H., Beynen, A.C., Dietary Carvacrol lowers body weight gain but Improves feed conversion in female broiler chickens. Journal of Applied Poultry Research, 12, 394-99, 2003.

19.Ocak, N., Erener, G., Burak, F., Sungu, M., Altop, A., Ozmen, A., Performance of broilers fed diets supplemented with dry peppermint (Mentha piperita L.) or thyme (Thymus vulgaris L.) leaves as growth promoter source. Czech Journal Animal Science, 53(4), 169-75, 2008.

20.Mendez - Zamora, G., Melendez, L. A.D., Hume, M., Michael E., Silva Vázquez, Ramón. Performance, blood parameters, and carcass yield of broiler chickens supplemented with Mexican oregano oil. Revista Brasileira de Zootecnia, 46(6), 515520, 2017.

21.BSS 9374:1982 - Meat and meat products. Determination of protein content. Bulgarian Institute for Standardization.

22.BSS 15437:1982 - Meat and meat products. Determination of the water content. Bulgarian Institute for Standardization

23.BSS 8549:1992 - Meat and meat products. Determination of fats. Bulgarian Institute for Standardization.

24.Zahariev, Z., Pinkas, A., Methods of experimentation, Slaughter Analysis and Carcass Evaluation in Cattle. Information and Propaganda, 1: 15-16, 1979.

25.Petrov, Y., Specific features of species and breed on microstructure of skeletal muscles during ontogenesis in productive animals. $\mathrm{PhD}$ thesis, Stara Zagora, Bulgaria, 1982.

26.Al-Kassie, G. A. M., Influence of two plant extracts derived from thyme and cinnamon on broiler performance. Pakistan Veterinary Journal, 29 (4), 169-173, 2009.

27.Fotea, L., Leonte, D., Ţugui I.,The effect of essential oil of thyme (thimus vulgaris) on to the quality of meat and carcasses of meat chicken broilers. Universitatea de stiinte Agricole si Medicina Veterinara Iasi Lucrari stiintifice, Seria Zootehnie, 52, 408-410, 2009.

28. Sevim, B., Gümüş, E., Harman, H., Ayasan,T., Başer, E., Altay, Y., Akbulut, K., Effects of Dietary Rosemary Essential 
Oil on Growth Performance, Carcass Traits and Some Hematological Values of Chukar Partridge. Turkish Journal of Agriculture Food Science and Technology, 8(2), 430435, 2020.

29.Lopez - Bote, C. J., Gray, J. G., Gomma, E. A., Flegal, C.J., Effect of dietary administration of oil extracts from rosemary and sage on lipid oxidation in broiler meat. British Poultry Science, 39, 235-40, 1998.

30.Govaris, A., Botsoglou, N., Papageorgiou, G., Botsoglou, E., Ambrosiadis, I., Dietary versus post-mortem use of oregano oil and/or $\alpha$-tocopherol in turkeys to inhibit development of lipid oxidation in meat during refrigerated storage. Int. J. Food Sci. Nutr. 55, 115-23, 2004.

31.Basmacioglu, H., Tokusoglu, O., Ergul, M., The effect of oregano and rosemary essential oils or $\alpha$-tocopheryl acetate on performance and lipid oxidation of meat enriched with n-3 PUFAs in broilers. South African Journal of Animal Science, 34, 197-210, 2004.

32.Botsoglou, N.A., Florou-Paneri, P., Botsoglou, E., Datos, V., Giannenas, I., Koidis, A. \& Mitrakos, P., The effect of feeding rosemary, oregano, safran and $\infty$ tocopheryl acetate on hen performance and oxidative stability of eggs. South African Journal Of Animal Science, 35, 143-151, 2005.

33.Alçiçek, A., Bozkurt, M., Çabuk, M., The effect of a mixture of herbal essential oils, an organic acid or a probiotic on broiler performance. South African Journal Of Animal Science, 34, 217-222, 2004.

34.Jamroz, D., Wiliczkiewicz, A., Wertelecki, T., Orda, J., Sukorupinska J., Use of active substances of plant origin in chicken diets based on maize and locally grown cereals. British Poultry Science, 46, 485-493, 2005.

35.Alçiçek, A., Bozkurt, M., Çabuk, M., The effect of an essential oil combination derived from selected herbs growing wild in Turkey on broiler performance. South African Journal of Animal Science, 33(2), 89-94, 2003.
OBLAKOVA M., et al.

36.Karakok, S. G., Ozogul, Y., Saler, M., Ozogul, F., Proximate analysis. Fatty acid profiles and mineral contents of meats: A comparative study. Journal of Muscle Foods, 21, 210-223, 2010.

37.Elmali, D.A., Yakan, A., Kaya, O., Elmali, M, Onk, K., Sahin, T., Durna, O., Effects of plant extracts and (essential) oil mixture on breast meat quality of Japanese quails (Coturnix coturnix japonica). Revue Méd Vét. 165(3-4), 104-110, 2014.

38.Herkel, R., Galik, B., Biro, D., Rolinec, M., Simko, M., Juracek, M., Arpasova, H., Anna W. A., The effect of a phytogenic additive on nutritional composition of turkey meat. Journal of Central European Agriculture, 17(1), 25-39, 2016.

39.Barbut, S., Occurrence of pale soft exudative meat in mature turkey hens. British Poultry Science, 38, 74-77, 1997.

40.Küçükyilmaz, K., Z. Kiyma, A., Akdağ, M., Çetinkaya, H., Atalay, A., Ateş, F., Gürsel, E., Bozkurt, M., Effect of lavender (Lavandula Stoechas) essential oil on growth performance, carcass characteristics, meat quality and antioxidant status of broilers. South African Journal of Animal Science, 47 (No. 2), 178-186, 2017.

41.Ribarski, S., Oblakova, M., Slaughter yield and quality of meat from wild turkey (meleagris gallopavo silvestris vieillot) reared in hunting reserve in south Bulgaria. Trakia Journal of Sciences, 14, 135-141, 2016.

42.Smet, K., Raes, K., Huyghebaert, G., Haak, L., Arnouts, S., De Smet, S., Lipid and protein oxidation of broiler meat as influenced by dietary natural antioxidant supplementation. Poultry Science, 87: 1682-1688, 2008.

43.İpçak, H. H., Alçiçek, A., Addition of Capsicum oleoresin, Carvacrol, Cinnamaldehyde and their mixtures to the broiler diet II: Effects on meat quality. Journal of Animal Science Technology, 60, 1-11, 2018. 